\title{
Interactions between bivalve filter feeding and oceanographic forcing drive the fluxes of organic matter and nutrients at an estuarine-coastal interface
}

\author{
Sorrel A. O'Connell-Milne, Stephen R. Wing*, Sutara H. Suanda, Jacquetta A. Udy, \\ Leonardo M. Durante, Nichola H. Salmond, Lucy C. Wing
}

Department of Marine Science, University of Otago, PO Box 56, Dunedin, New Zealand, 9054

\begin{abstract}
Fluxes of nutrients and organic matter between estuaries and the open coast comprise an important component of ecosystem connectivity. Nevertheless, relatively little is known about how oceanographic processes, for example onshore retention of water in the coastal boundary layer, interact with major sinks for particulate organic matter such as bivalve filter feeding within inlets and estuaries. To investigate this interaction, total fluxes of water, nutrients $\left(\mathrm{NH}_{4}, \mathrm{NO}_{\mathrm{x}}\right.$ and $\mathrm{PO}_{4}$ ) and chlorophyll a between Waitati Inlet on the wave-exposed coast of the South Island, New Zealand, and the coastal ocean were quantified over 40 tidal cycles. We found declines in total flux of phytoplankton and increases in flux of $\mathrm{NH}_{4}$ between flood and ebb tides. Net declines in phytoplankton biomass followed a Type II functional response curve, consistent with consumption by the large biomass of filter feeding bivalves within the inlet; however, an asymptote was not reached for the highest concentrations, indicating that feeding was likely limited by exposure time rather than concentration of food relative to biomass. An information-theoretic framework was then used to infer the most likely combination of environmental conditions influencing total fluxes of phytoplankton into the inlet. Onshore wind stress, wave transport and salinity explained $90 \%$ of the variation in flux of phytoplankton entering the inlet on flood tides. These results highlight the importance of the interaction between oceanographic forcing and bivalve filter feeding in modulating material dynamics and connectivity between estuaries and the coastal ocean.
\end{abstract}

KEY WORDS: Organic matter flux - Nutrients - Filter feeding bivalves - Ecosystem function · Tidal exchange $\cdot$ Physical-biological coupling

\section{INTRODUCTION}

Tidally driven exchanges of organic matter and nutrients between estuaries and the coastal ocean are influenced by a chain of vital processes that together comprise coastal ecosystem function. Odum's (1980) seminal paper detailing the 'outwelling hypothesis' provided a landmark in ecosystem ecology by focussing attention on material fluxes between adjacent environments. The resulting framework led to modern views of ecosystems as dynamic networks connected by the flow of energy and materials

\footnotetext{
${ }^{*}$ Corresponding author: steve.wing@otago.ac.nz
}

(Barnes et al. 2018). Here it was stipulated that estuaries can either have a net export, or import, of organic carbon and nutrients, depending on the influences of biogeochemical processes in sediments, geomorphology, trophic processes, tidal flushing and exogenous forcing (e.g. Newell et al. 2016, McCarthy et al. 2019). Efforts to integrate total fluxes of organic matter and nutrients across a range of marine systems have further highlighted the pivotal role of estuaries in biogeochemical cycling in the coastal ocean (Nixon 1980, Childers et al. 2000, Snelgrove et al. 2018).

() The authors 2020. Open Access under Creative Commons by Attribution Licence. Use, distribution and reproduction are unrestricted. Authors and original publication must be credited. 
In many systems, filter feeding bivalves play a dominant role in mediating fluxes of organic matter and nutrients between pelagic and benthic environments (Thrush et al. 2006, Norkko et al. 2013, Snelgrove et al. 2018). The role of bivalve filter feeders in processing and delivering organic matter to the benthos, bioturbation and stimulating denitrification pathways and directly influencing fluxes of nutrients highlights the critical role of bivalves in the internal material dynamics of estuaries (Dame 1993, Newell et al. 2002, Greenfield et al. 2016, Winder et al. 2017). As a consequence, via tidal flushing, bivalves also alter the flux of organic matter and nutrients between open coastal and estuarine environments (Dame \& Dankers 1988, Dame 1993). The magnitude of bivalve-mediated material fluxes and the farreaching effects in coastal ecosystems have been repeatedly demonstrated in systems where bivalves have been either lost or severely depleted. Examples include records of extensive bivalve decline in the Dutch Wadden Sea (Beukema \& Cadée 1996), New York Harbor and Chesapeake Bay (Kirby 2004), the upper Gulf of California (Rodriguez et al. 2001) and Doubtful Sound in New Zealand's Fiordland region (Tallis et al. 2004). Declines in bivalve populations have been associated with dramatic changes in fluxes of organic matter (e.g. Dame \& Dankers 1988) and nutrients (Newell 1988, Fulford et al. 2010), as well as shifts in benthic food web structure (e.g. Jack et al. 2009, McLeod et al. 2010) and habitat provision (e.g. Rutger \& Wing 2006, McLeod \& Wing 2008). These functional changes highlight the position of bivalves as ecosystem engineers, with the loss of bivalves often accompanied by the loss of essential ecosystem services.

Efforts to quantify the magnitude of bivalve mediated fluxes of organic matter and nutrients in whole systems have progressed from upscaling individual laboratory-based flux measurements (Doering \& Oviatt 1986, Rodhouse \& Roden 1987, Jones et al. 2011, 2017), to extrapolation of in situ flux measurements made in tidal flumes to whole beds or reefs of bivalves (e.g. Dame \& Dankers 1988), to integration of total fluxes and estimates of carrying capacity for whole estuarine systems based on residence time of water in estuaries (Dame \& Prins 1998, Srisunont \& Babel 2016). These studies provide an important context for evaluating the ecosystem services provided by bivalve filter feeding and the capacity for restoration and expansion of bivalve mariculture within individual estuaries (e.g. Dame \& Prins 1998, Srisunont \& Babel 2016)

Relatively little is known about how coastal oceanographic processes outside of estuaries influence inter- nal material dynamics, which provided the rationale for the current study. The ability to continuously measure net material fluxes between the open coast and estuarine environments, originally set as a goal by Odum (1980), provides the basis upon which to directly assess how materials are exchanged and investigate how exogenous oceanographic forcing potentially mediates patterns of exchange (e.g. Childers et al. 2000). Tidal exchange between the open coast and estuaries can be quantified by continuous measurement of water flow through a cross section of the entry channel (Kjerfve \& Proehl 1979, Kjerfve et al. 1982) and coupled with periodic measurement of particulate organic carbon (POC) and nutrient concentrations (Farfan \& Alvarez-Borrego 1983, Nakamura \& Kerciku 2000, Falco et al. 2010) to estimate net material fluxes. In this context, the residence time of water in an inlet becomes an important emergent property, being a rough measure of the time over which water is available to be filtered by bivalves (e.g. Rynne et al. 2016). Further, calculations of exposure time (Delhez 2013), which considers the repeated exchange of water between the coastal ocean and an estuary, extends this definition to recognize external coastal retention processes in the nearshore environment that may result in prolonged entrainment and potential repeated exposure of water to be filtered or modified within estuarine environments (Viero \& Defina 2016).

The magnitude of ocean-estuary water exchange is influenced by exogenous processes within the inlet such as freshwater flow (Murrell et al. 2007), but also by oceanographic processes acting on the adjacent open coast such as cross-shelf transport and mixing due to surface waves (e.g. Hench et al. 2008) or winddriven currents (Klinck et al. 1981). In many temperate systems, variability in coastal retention of neritic water, and consequentially the exposure time of water in estuaries, occurs at the headland-embayment scale and is forced by shifts between upwellingand downwelling-favourable winds (e.g. Wing et al. 1998, Suanda et al. 2016). Accordingly, the focus of the present work was to resolve how coastal oceanographic conditions likely interact with bivalve filter feeding to influence the net fluxes of materials between the coastal ocean and an estuary on an open, wave-exposed coast. We ask the general questions: (1) How do coastal oceanographic conditions influence the delivery of phytoplankton into estuaries? (2) How do influxes of phytoplankton likely interact with bivalve filter feeding to modify net fluxes of organic matter between the estuary and the coastal ocean?

The present study was based in Waitati Inlet, a well-flushed tidally dominated inlet situated on the 
wave-exposed east coast of South Island, New Zealand (see Fig. 1). The inlet has a high density of bivalves, primarily the filter feeding cockle Austrovenus stutchburyi (up to 1800 ind. $\mathrm{m}^{-2}$ ). The cockle biomass estimate (mean $\pm \mathrm{SE}$ ) within the inlet was $14161.7 \pm 1081.8 \mathrm{t}$ at the time of our study (Miller \& Black 2019). Commercial cockle harvesting can remove up to $1008 \mathrm{t} \mathrm{yr}^{-1}$, as well as additional removal by recreational and customary fishing. Removal of shellfish biomass can have broader implications for the ecological community and estuary function (O'Connell-Milne 2016). The capacity of the $A$. stutchburyi population to filter water in the inlet likely comprises a dominant sink for organic carbon in the system (Smith et al. 2010, Kainamu 2011).

We used continuous measurements of water flow, depth and chlorophyll a ( $\mathrm{chl}$ a), as well as discrete samples of nutrient concentrations collected during ebb and flood tides from the well-mixed entrance channel of the inlet to estimate net tidally induced fluxes of water, phytoplankton and nutrients between Waitati Inlet and the coastal ocean. Environmental data on wind stress, ocean wave transport, solar irradiation, temperature and rainfall provided the basis for a statistical model to infer likely influences of exogenous oceanographic forcing on influxes of chl a from the coastal ocean to the estuary. These data were used to assess how changes in total phytoplankton biomass entering the inlet during flood tides, and hence made available to bivalve filter feeding, varied among periods with different coastal oceanographic conditions. We then used data on the biomass and population structure of the abundant bivalve A. stutchburyi to estimate the likely contribution of bivalve filter feeding to net fluxes of phytoplankton between the coastal ocean and Waitati Inlet. Our results have important implications for understanding the interactions between coastal oceanographic forcing and bivalve filter feeding on the net fluxes of organic material between estuaries and the coastal ocean.

\section{MATERIALS AND METHODS}

\subsection{Study site and instrument mooring}

Waitati Inlet is classified as a shallow, intertidally dominated estuary (Robertson et al. 2016). It is permanently open and considered well-flushed and tidally dominated on the scale of New Zealand coastal inlets (Heath 1976). The inlet area spans $6.2 \mathrm{~km}^{2}$, with intertidal flats comprising $86 \%$, spanning $5.2 \mathrm{~km}^{2}$ excluding saltmarsh habitat. The catchment covers an area of approximately $92.8 \mathrm{~km}^{2}$ (Hume et al. 2016). As is characteristic of tidal lagoons such as Waitati Inlet, the tidal prism accounts for a majority (76.5\%) of the total basin volume at spring high tide (7559 $\left.191 \mathrm{~m}^{3}\right)$ (Hume et al. 2016). Thus, the majority of the water within the inlet is exchanged with the adjacent coastal ocean at each tide. The inlet has a mean depth of $1.2 \mathrm{~m}$ at spring high tide, however channels in the inlet can reach depths of 3-4 m. The inlet is connected to the coastal ocean through a single narrow channel with maximum depth of approximately $3.5 \mathrm{~m}$. The semidiurnal tides form strong tidal currents at the entrance as water exchanges through the constrained channel resulting in a well-mixed water column (Heath 1976).

We measured net fluxes of water, phytoplankton and nutrients over a series of 40 tidal cycles, covering 5 discrete sampling periods (deployments) in the austral spring and summer of 2018-2019 in order to resolve how exogenous forcing influenced delivery of phytoplankton to the inlet. Spring and summer were targeted to provide the period of highest primary production and material fluxes between the estuary and coastal ocean. Measurements of water properties were collected at 1 min sample intervals from instruments on a bottom-mounted metal frame mooring deployed at low tide in $3.5 \mathrm{~m}$ water depth relative to high tide in the main channel of Waitati Inlet (Fig. 1). Salinity, temperature and pressure were recorded by an XR-420 model RBR data logger. A Turner Designs ${ }^{\circledR}$ C3 submersible fluorometer, complete with wipers and shade cap, recorded optical fluorescence at 635 and $850 \mathrm{~nm}$ to infer water column chl a concentration and turbidity respectively. For 3 of the 5 deployments, an upward-looking $2 \mathrm{MHz}$ Nortek AS Aquadopp Profiler measured horizontal water column velocity in $25 \mathrm{~cm}$ vertical bins. Twelve independent velocity samples were averaged to $1 \mathrm{~min}$ profiles. In the remaining deployments, a flow model was constructed to infer tidal flows based on bottom pressure measurements from the RBR data logger (see Section 2.5). Deployments spanned 4 September to 4 December 2018 through the spring and early summer. Deployments were planned to cover a similar timing of tidal cycles with high tide during the middle of the day to ensure maximum daytime and minimum night-time productivity within the estuary.

\subsection{Velocity profile processing}

After each deployment, Aquadopp velocity measurements were further processed. Each profile was 


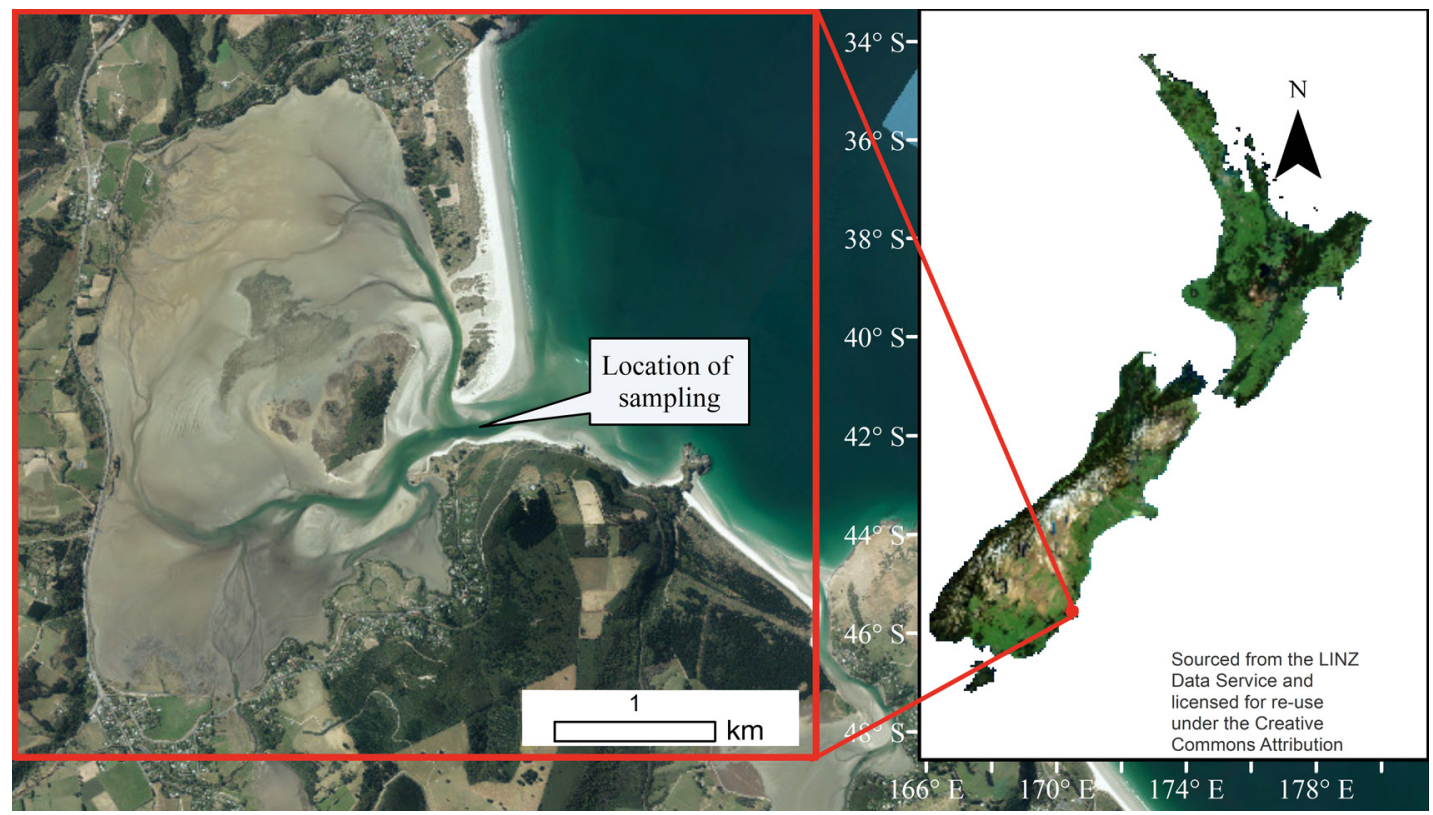

Fig. 1. Location and aerial image of Waitati Inlet at low tide. Text box indicates the main channel location of moored monitoring and water sampling

screened for surface contamination, where all measurements within $50 \mathrm{~cm}$ (2 bins) of the sea surface were discarded. Compass-coordinate Aquadopp velocities were rotated to align with the orientation of the main channel, equivalent to the principal axes coordinate system as determined by depth-averaged Aquadopp velocities. In the dominant along-channel direction, velocity profiles had no detectable vertical structure. The result justified use of the depth-average flow as a representative velocity directed incoming-to, and outgoing-from, Waitati Inlet. Cross-channel (lateral) variation in velocity structure was not quantified in the present study due to the well-mixed flow and representative positioning of the monitoring equipment within the deepest point at the center of the confined channel.

\subsection{Tidal duration identification}

Bottom pressure measurements were used to identify the duration of each flood and ebb tide. The $1 \mathrm{~min}$ measurements were low-pass-filtered with a filter half-power of $45 \mathrm{~min}$ and first-differenced to obtain their time derivative. Zero-crossings in the bottom pressure time derivative were identified as slack tide periods, marking the transition between individual flood-to-ebb or ebb-to-flood tide and providing temporal integration limits for exchange estimates.

\subsection{Tidal exchange through channel}

At high tide, a hand-held depth sounder was used to collect measurements of the bottom profile across the Waitati Inlet main channel where the monitoring equipment was moored. The bottom profile was extrapolated to a time-variable channel cross-sectional area informed by measurements of tidal height from bottom pressure. Multiplication of incoming-outgoing flow velocity $\left(\mathrm{m} \mathrm{s}^{-1}\right)$ with the time-variable cross-sectional area of the channel $\left(\mathrm{m}^{2}\right)$ gave an estimate of bulk transport of water $\left(\mathrm{m}^{3} \mathrm{~s}^{-1}\right)$ into and out of Waitati Inlet. Integration of bulk transport over the duration of a flood and ebb tide yielded the tidal exchange; the total volume of water transported into, and out of, Waitati Inlet over each tidal cycle. We found little difference in tidally integrated volume transport over the 40 tides measured in the present study (data not shown).

Similarly, material flux into and out of Waitati Inlet was estimated. The product of total volume flux $\left(\mathrm{m}^{3}\right.$ $\mathrm{s}^{-1}$ ) and chl a concentration $\left(\mu \mathrm{g} \mathrm{l}^{-1}\right)$ provided an estimate of the total flux of material. Integration in time over the duration of a flood and ebb tide yielded the cumulative tidal material exchange transported into and out of Waitati Inlet per tide (i.e. $\mathrm{kg} \mathrm{tide}^{-1}$ ). The difference in cumulative mass between a flood and subsequent ebb tide yielded the cumulative material in $\mathrm{kg}$ tidal $\mathrm{cycle}^{-1}$. 


\subsection{Flow model of tidal exchange through channel}

As water current velocity was not measured at all deployments, an empirical model of tidal currents as a function of channel depth was used to estimate tidal exchange (Boon \& Byrne 1981). The conservation of volume principle for an inlet connected to the ocean through a single channel can be written by equating the time-rate of sea level change to the cross-section average current velocity:

$$
A \frac{\mathrm{d} h}{\mathrm{~d} t}=A_{\mathrm{c}} V
$$

where $A$ is the inlet surface area, $A_{\mathrm{C}}$ the channel cross-sectional area, $V$ is the time-variable, crosssection mean current velocity, $h$ is the inlet sea level and $t$ is time (min). Aquadopp mean velocity and RBR bottom pressure data from the second deployment (see Fig. 2) (18-25 Sept 2018) spanned 12 full tidal cycles. These data were used to determine the ratio $\left(A / A_{C}\right)$ from the slope of a linear least squares regression with the time derivative of sea level $(\mathrm{d} h / \mathrm{d} t)$ as predictor variable and $V$ as the response variable. The validity of the flow model was assessed against flow data collected on Deployment 1 (4-11 Sept 2018) and Deployment 3 (16-23 Oct 2018) to ensure modelled flow correctly represented conditions across other deployments. Although ebb-tide currents were better predicted than flood-tide currents, the overall regression had high skill $\left(\mathrm{r}^{2}=0.85\right)$ with a small $y$ intercept. Inclusion of a temporal lag between variables did not greatly increase model significance; therefore, the regression coefficients at zero lag were used to predict tidal currents for deployments without current measurements.

\subsection{Environmental data}

Environmental data were sourced from a variety of local sources. A meteorological station mounted on the roof of the University of Otago's Department of Physics building (approximately $45 \mathrm{~m}$ above sea level, $15 \mathrm{~km}$ from Waitati Inlet) collected wind speed and direction, incident solar radiation and air temperature measurements at $5 \mathrm{~min}$ intervals. Wind speed was converted to wind stress with standard bulk oceanic flux procedures (Large \& Pond 1981). Rain data was accessed from a rain gauge operating within the Waitati catchment. For the South Island of New Zealand, wave conditions are monitored by Canterbury Regional Council (Environment Canterbury) with a Datawell directional wave-rider buoy moored in $75 \mathrm{~m}$ of water, $17 \mathrm{~km}$ offshore $\left(43^{\circ} 45^{\prime} \mathrm{S}, 173^{\circ} 20^{\prime} \mathrm{E}\right)$. Significant wave height, peak period and mean wave direction were used to estimate the surface wave-driven transport (Stokes' drift) for monochromatic deep-water waves (Longuet-Higgins 1953). For environmental regression modelling, wave conditions were separated into north-northeast $\left(0-110^{\circ}\right.$ incidence) and southsoutheast conditions (110-270 incidence).

\subsection{Water sampling}

Water samples were collected at mid-tide for both flood and ebb tides for 3 consecutive days of each deployment. To calibrate chl a readings from the deployed C3 fluorometer, triplicate 1.51 water samples were vacuum-filtered through glass-fiber filters (Whatmann GF/F, 47mm), extracted in $96 \%$ ethanol and measured spectrophotometrically. Concurrently, water samples to assess nutrient concentrations were collected in triplicate, filtered at $0.45 \mu \mathrm{m}$ and frozen at $-20^{\circ} \mathrm{C}$ until analysis. Dissolved nutrient concentrations $\left(\mathrm{NH}_{4}, \mathrm{NO}_{\mathrm{x}}\right.$ and $\left.\mathrm{PO}_{4}\right)$ were determined on a $\mathrm{La}$ Chat QuikChem 8500 Series 2 channel nutrient autoanalyzer at the Portobello Marine Laboratory, University of Otago.

\subsection{Carbon and nitrogen content of suspended particulate organic matter (SPOM)}

To quantify total particulate organic carbon and nitrogen, 2-3 l of seawater was pre-filtered through a $200 \mu \mathrm{m}$ mesh, vacuum-filtered onto pre-combusted glass fiber filters (Whatman GF/F, 47mm) until clogged, acid-fumed with $\left(\mathrm{H}_{2} \mathrm{SO}_{3}\right)$ for $6 \mathrm{~h}$ and dried at $60^{\circ} \mathrm{C}$ prior to analysis. All samples were analyzed in triplicate on a Europa 20-20 update stable isotope mass spectrometer (Europa Scientific) interfaced to a Carlo Erba elemental analyzer (NA1500; Carlo Erba) in continuous flow mode at the Isotrace lab in the Department of Chemistry, Otago University, using standard protocols.

\subsection{Estimates of population structure and clearance rates of Austrovenus stutchburyi}

Austrovenus stutchburyi were randomly collected ( $n=3869$ ) from established survey strata covering the whole of Waitati Inlet (Irwin 2004). Total length $(\mathrm{mm})$ and wet weight $(\mathrm{g})$ of each individual were measured to resolve size and weight distributions for 
the population. For a subset of 174 individuals, all tissue was removed from the shell and placed into preweighed crucibles and dried at $60^{\circ} \mathrm{C}$ for a minimum of $4 \mathrm{~d}$ to obtain tissue dry weight (gDW). Average length $(\mathrm{mm})$, whole wet weight $(\mathrm{g})$ and tissue DW were then calculated based on the size and weight distribution of the population. The relationship between whole wet weight and tissue DW was used to calculate the tissue DW represented by the whole inlet fisheries stock assessment of $14161.7 \pm 1081.8 \mathrm{t}$ (Miller \& Black 2019).

Change in the total fluxes of chl a $(\mathrm{g})$ between flood and ebb tides were then used to calculate the fractions of the water exchanged between the inlet and the coastal ocean that were cleared during each of the 40 observed tidal cycles. We then calculated the volume of water cleared based on the total flux of water for each tidal cycle. Clearance rate $\left(\mathrm{lgDW}^{-1}\right.$ tidal cycle ${ }^{-1}$ ) was then estimated based on volume of water filtered (l) and total DW of the A. stutchburyi population. We then estimated the volume that would likely be filtered by each individual in the size distribution based on weight-specific clearance rates. These estimates, based on the assumption that $A$. stutchburyi accounted for the observed declines in chl $a$, were then compared with experimentally derived values for clearance rates in estuarine bivalves.

\subsection{Statistical analysis}

We used generalized linear models in JMP v.14.2.0 (SAS Institute) with the factors tide (fixed, flood vs. ebb) and sample period (ordinal, 5 levels) to test for differences in (1) cumulative mass of chl a $\left(\mathrm{kg} \mathrm{tide}^{-1}\right)$ and (2) cumulative mass ( $\mathrm{kg} \mathrm{tide}^{-1}$ ) and average concentrations of $\mathrm{NH}_{4}, \mathrm{PO}_{4}\left(\mu \mathrm{mol} \mathrm{l} \mathrm{l}^{-1}\right)$ and $\mathrm{NO}_{\mathrm{x}}\left(\mu \mathrm{g} \mathrm{l}^{-1}\right)$ between flood and ebb tides during each tidal cycle among the 5 deployments.

Known relationships between the concentration of chl $a$ and the concentration of carbon for temperate coastal phytoplankton allowed for estimates of POC transport due to phytoplankton on each tidal exchange to be calculated (Jakobsen \& Markager 2016). We then examined the relationship between cumulative mass of POC $\left(\mathrm{kg}\right.$ tide $\left.^{-1}\right)$ on flood tides, and the net change in cumulative mass of POC (kg tidal cycle $^{-1}$ ) between flood and ebb tides. In this case, we used nonlinear fitting with Newton-based iteration in JMP of the Type II functional response equation, where the net change in carbon ( $\mathrm{kg} \mathrm{tide}^{-1}$ ) was calculated as the difference between cumulative carbon $\left(\mathrm{kg} \mathrm{tide}^{-1}\right)$ on the flood tide and cumulative carbon ( $\mathrm{kg} \mathrm{tide}^{-1}$ ) on the ebb tide. The 'attack rate' (a) denotes the rate at which a consumer encounters food per unit density, and the 'handling time' $(h)$ is the average time spent processing a food item:

Net change in carbon $(\mathrm{kg})=\frac{(a \cdot \text { carbon }(\mathrm{kg}) \text { Flood })}{(1+a h \cdot \text { carbon }(\mathrm{kg}) \text { Flood })}$

A generalized linear model in JMP with factors time (fixed, day vs. night), tide (fixed, flood vs. ebb) and sample period (random, 5 levels) and the interaction of time $\times$ tide was used to test the difference in the cumulative mass of carbon $\left(\mathrm{kg} \mathrm{tide}^{-1}\right)$ between flood and ebb tides during day and night. These tests were focussed on controlling for phytoplankton growth associated with light saturating conditions during daylight hours, compared to dark treatments. Because we timed our sampling periods to correspond with times when low tide occurred at dawn, we were able to carry out a robust analysis of the effects of time on POM fluxes for whole tidal cycles.

Generalized linear models in JMP were used to test for the effects of exogenous forcing in the form of environmental conditions including wind stress, ocean wave transport, solar irradiation, temperature and rainfall on the cumulative mass of chl a $\left(\mathrm{kg} \mathrm{tide}^{-1}\right)$ entering the inlet during flood tides. We used model selection procedures in an information-theoretic framework to select the most parsimonious group of models to statistically explain physical delivery of phytoplankton to the inlet. For the best set of models, we used Akaike's information criterion corrected for small sample sizes $\left(\mathrm{AIC}_{\mathrm{c}}\right)$ to assess the relative explanatory power of salinity and a range of wind and wave statistics for describing the variability in fluxes of chl $a$ into the inlet.

\section{RESULTS}

Wind stress and wave transport conditions varied in the coastal ocean during the 5 deployments, with strong onshore wind stress and wave transport observed during Deployments 1 and 5, and periods of offshore wind stress observed during Deployments 2, 3 and 4 (Fig. 2A,B). There were significant periods of high air temperature $\left({ }^{\circ} \mathrm{C}\right)$ during Deployments 2, 3 and 4 , high irradiance $\left(\mathrm{W} \mathrm{m}^{-2}\right.$ ) during Deployments 3,4 and 5 and significant rainfall $\left(\mathrm{mm} \mathrm{h}^{-1}\right)$ events observed in each of the deployments, with a large period of rainfall preceding Deployment 5 (Figs. 2C,D,E).

Time-series of depth $(\mathrm{m})$, flow $\left(\mathrm{m} \mathrm{s}^{-1}\right)$ and chl a $(\mu \mathrm{g}$ $\mathrm{l}^{-1}$ ) in the entrance channel over $3 \mathrm{~d}$ provided a typi- 

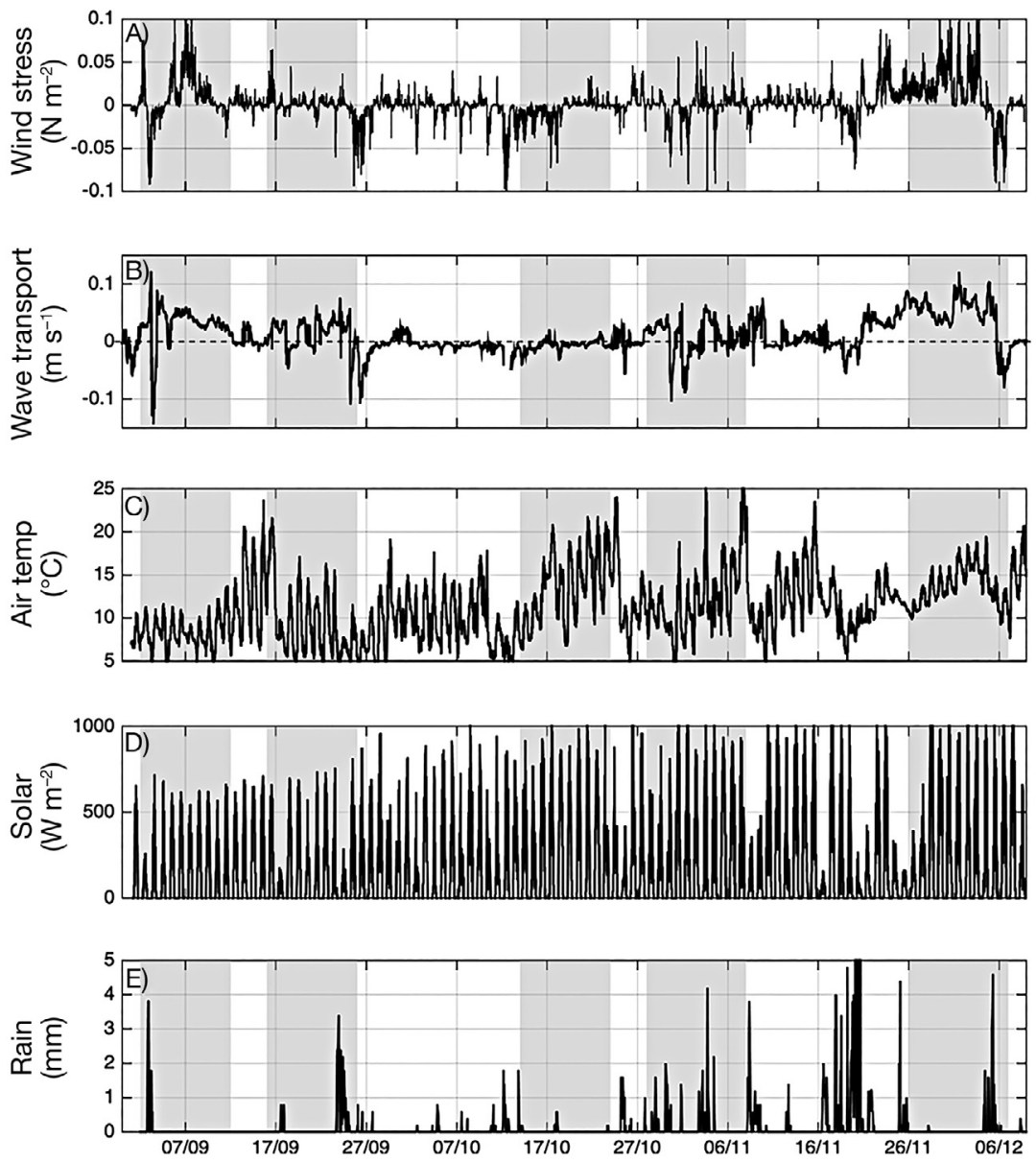

Fig. 2. Environmental conditions during deployments: (A) wind stress, (B) wave transport, (C) air temperature, (D) irradiance and (E) rainfall. Grey shading: 5 deployment periods cal picture of variation within and among tidal cycles (Fig. 3). We observed a slightly asymmetric flow pattern through the channel among tidal cycles with slightly higher amplitudes of flood tide peak flows compared with peak flows during ebb tides (Fig. 3). At high tide, the entrance channel had a cross-sectional area of $730 \mathrm{~m}^{2}$ with flow peaking at $1.54 \mathrm{~m} \mathrm{~s}^{-1}$ during mid-tide. On the flood tide, concentrations of chl a were mostly synchronous with incoming water flow, indicating the relatively large transport of chl a from the coastal ocean into Waitati Inlet (Fig. 3). On ebb tides, significantly lower concentrations of chl a were observed, indicating the relatively smaller transport of chl a out of Waitati Inlet (Fig. 3).

Results of the generalized linear model with the factors tide (fixed, flood vs. ebb) and sample period (ordinal, 5 levels) indicated that the cumulative flux of chl a $\left(\mathrm{kg} \mathrm{tide}^{-1}\right)$ entering the inlet during flood tides $(\mathrm{n}=40)$ was higher than the flux of chl a $(\mathrm{kg}$ tide $^{-1}$ ) leaving the inlet during ebb tides $(n=40)$, indicating a net positive transport of phytoplankton into the inlet (whole model: $F_{4,75}=33.32, \mathrm{p}=$ 0.0001 ; tide: $F=45.22, \mathrm{p}=0.0001)$
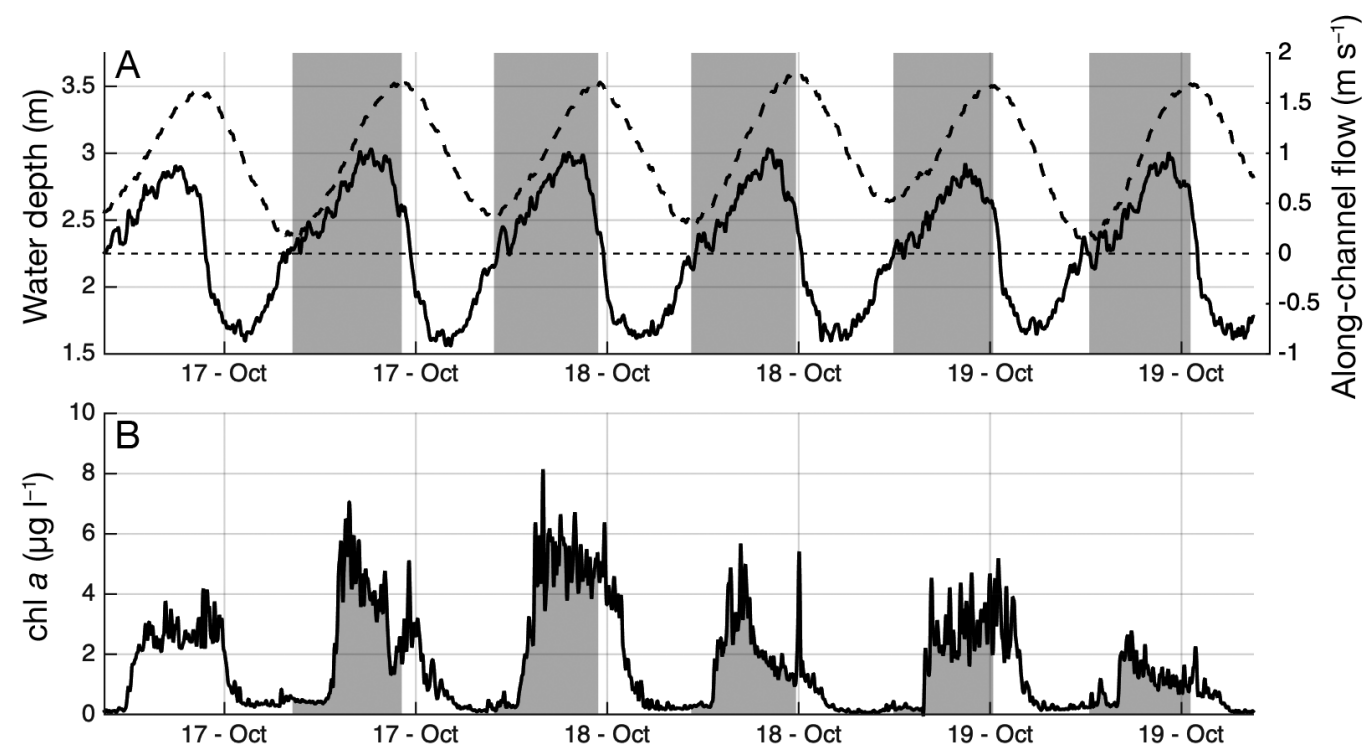

Fig. 3. Six days of deployment data showing (A) water depth (dashed line), along-channel flow (solid line) and (B) concentration of chl $a$. Grey shading in (A): periods of flood tide used for cumulative flux integrations; grey shading in (B): chl $a$ values included in cumulative flood chl a flux estimates 


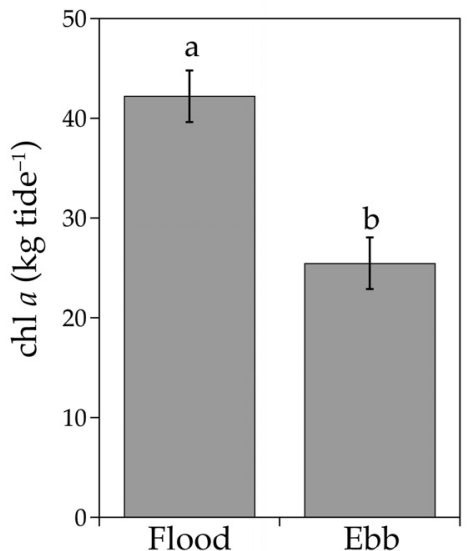

Fig. 4. Mean ( \pm 1 SE) cumulative flux of chl a across all deployments transported on flood vs. ebb tides. Levels not connected by the same letter are significantly different

(Fig. 4). Conversely, the average concentrations of $\mathrm{NH}_{4}$ transported during flood tides $(0.44 \pm 0.11 \mu \mathrm{mol}$ $\mathrm{I}^{-1}$ ) were lower than the average concentrations during ebb tides $\left(1.10 \pm 0.10 \mu \mathrm{mol} \mathrm{l}^{-1}\right)\left(\mathrm{NH}_{4}\right.$ : tide, $F_{1,33}=$ $58.78, \mathrm{p}=0.0001)$. The cumulative flux of $\mathrm{NH}_{4}(\mathrm{~kg}$ tide $^{-1}$ ) entering the inlet during flood tides was lower than the flux of $\mathrm{NH}_{4}\left(\mathrm{~kg}_{\text {tide }}{ }^{-1}\right)$ leaving the inlet during ebb tides, indicating a net positive transport of $\mathrm{NH}_{4}$ out of the inlet (whole model: $F_{4,15}=8.63, \mathrm{p}=$

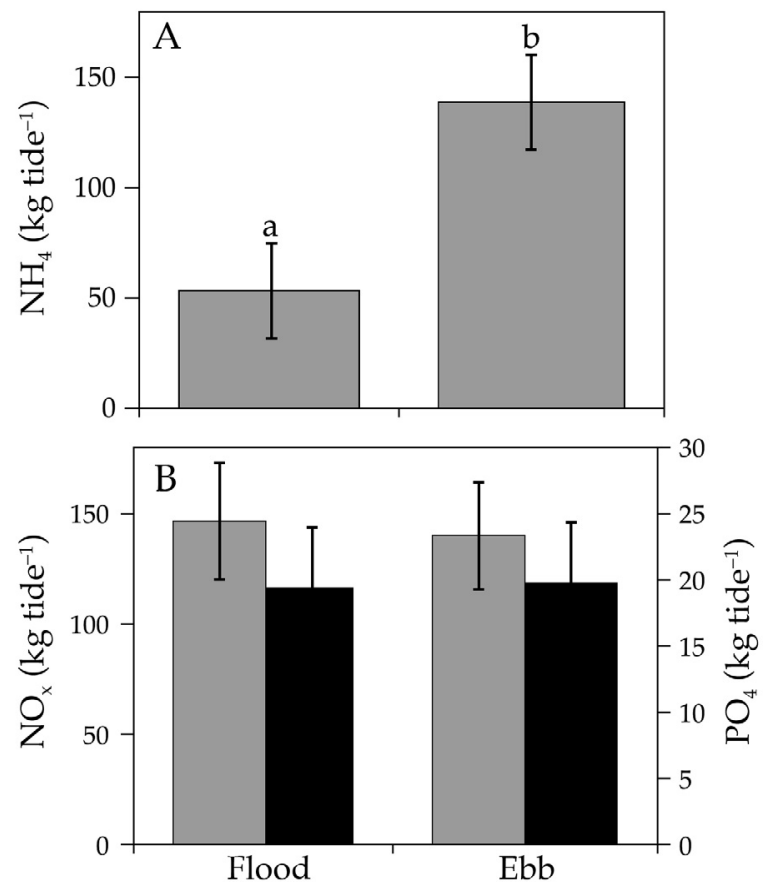

Fig. 5. Mean $( \pm 1 \mathrm{SE})$ total flux of (A) $\mathrm{NH}_{4}$, (B) $\mathrm{NO}_{\mathrm{x}}$ and $\mathrm{PO}_{4}$ transported during flood vs. ebb tides. (A) Levels not connected by the same letter are significantly different
0.0008; tide: $F=17.22, \mathrm{p}=0.0009$ ) (Fig. 5A). Concentrations of $\mathrm{NO}_{\mathrm{x}}$ and $\mathrm{PO}_{4}$ measured during flood tides $\left(\mathrm{NO}_{\mathrm{x}}: 19.56 \pm 2.72 \mathrm{ug} \mathrm{l}^{-1} ; \mathrm{PO}_{4}: 0.036 \pm 0.009 \mu \mathrm{mol} \mathrm{l}^{-1}\right)$ were not significantly different $(\mathrm{p}>0.05)$ than the concentrations $\left(\mathrm{NO}_{\mathrm{X}}: 17.48 \pm 2.70 \mu \mathrm{g} \mathrm{l}^{-1}{ }_{;} \mathrm{PO}_{4}: 0.044 \pm\right.$ $\left.0.008 \mu \mathrm{mol} \mathrm{l}^{-1}\right)$ measured during ebb tides $\left(\mathrm{NO}_{\mathrm{x}}\right.$ : tide, $F_{1,33}=0.97, \mathrm{p}=0.33 ; \mathrm{PO}_{4}$ : tide, $F_{1,33}=1.33, \mathrm{p}=0.26$ ). Similarly, cumulative fluxes of $\mathrm{NO}_{\mathrm{x}}$ and $\mathrm{PO}_{4}(\mathrm{~kg}$ tide $^{-1}$ ) were not different between flood and ebb tides $\left(\mathrm{NO}_{\mathrm{x}}\right.$ : tide, $F_{1,14}=0.93, \mathrm{p}=0.35 ; \mathrm{PO}_{4}$ : tide, $F_{1,15}=$ 0.007, $\mathrm{p}=0.93$ ) (Fig. 5B).

Cumulative fluxes of carbon $\left(\mathrm{kg} t i d \mathrm{e}^{-1}\right)$ on flood tides versus net changes in carbon ( $\mathrm{kg}$ tidal $\mathrm{cycle}^{-1}$ ) between flood and ebb tides indicated a curvilinear relationship (Fig. 6). On average $43 \pm 2.2 \%$ of POM was depleted from incoming water while in the inlet. The relationship between flux of carbon $\left(\mathrm{kg} \mathrm{tide}^{-1}\right)$ on flood and ebb tides during daytime and night-

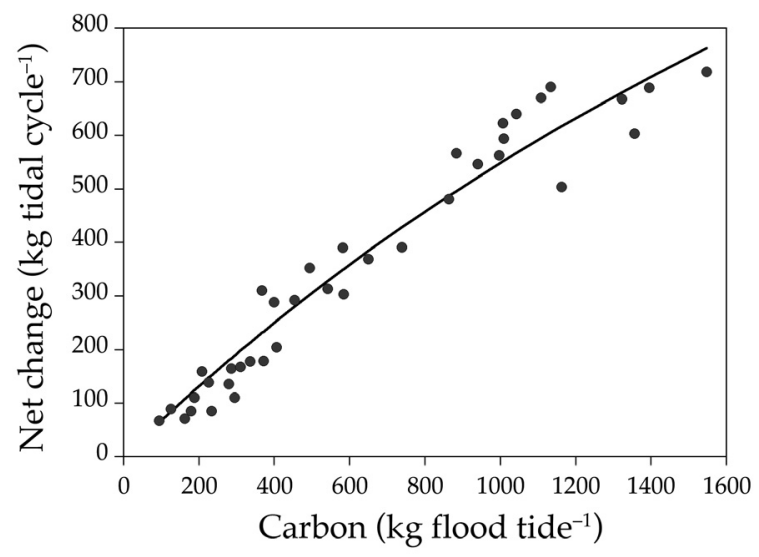

Fig. 6. Cumulative flux of carbon on flood tides vs. net changes in carbon between flood and ebb tides. Data fitted with a Type II functional response curve

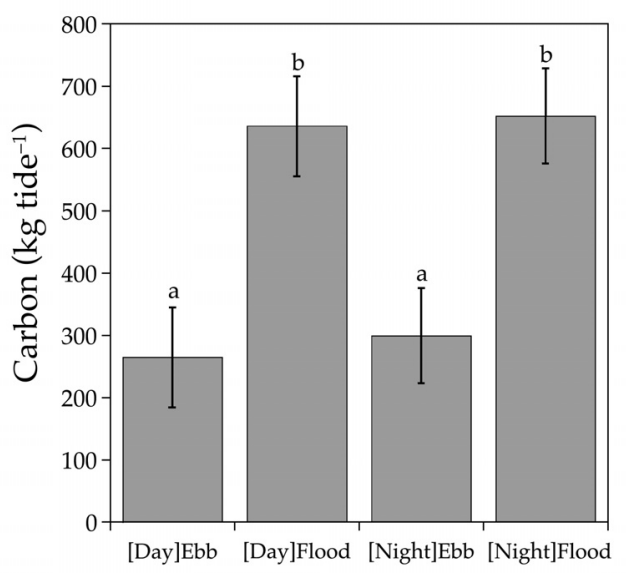

Fig. 7. Mean $( \pm 1 \mathrm{SE})$ flux of carbon on flood and ebb tides during daytime and night-time deployments of oceanographic instruments. Levels not connected by the same letter are significantly different 
time deployments indicated no significant difference in the net change of carbon associated with time of day (whole model: $F_{6,73}=22.47, \mathrm{p}=0.0001$; time $\times$ tide: $F=0.029, \mathrm{p}=0.87$ ) (Fig. 7).

Results of generalized linear models between salinity, wind speed and north wave height on cumulative mass of chl a $\left(\mathrm{kg} \mathrm{tide}^{-1}\right)$ during a flood tide indicated that $90 \%$ of the variability in $\mathrm{chl}$ a $(\mathrm{kg}$ tide $^{-1}$ ) could be statistically explained by the combined model (Fig. 8). Results of $\mathrm{AIC}_{\mathrm{C}}$ analysis demonstrated that each of the 3 environmental variables were the most important predictors of chl a total flux on flood tides with factor weightings ranging from 0.91-1.0 (Table 1). Under low salinity conditions with onshore winds and waves, chl $a$ on the incoming tide increased consistent with coastal retention of the outwelled water from the inlet.

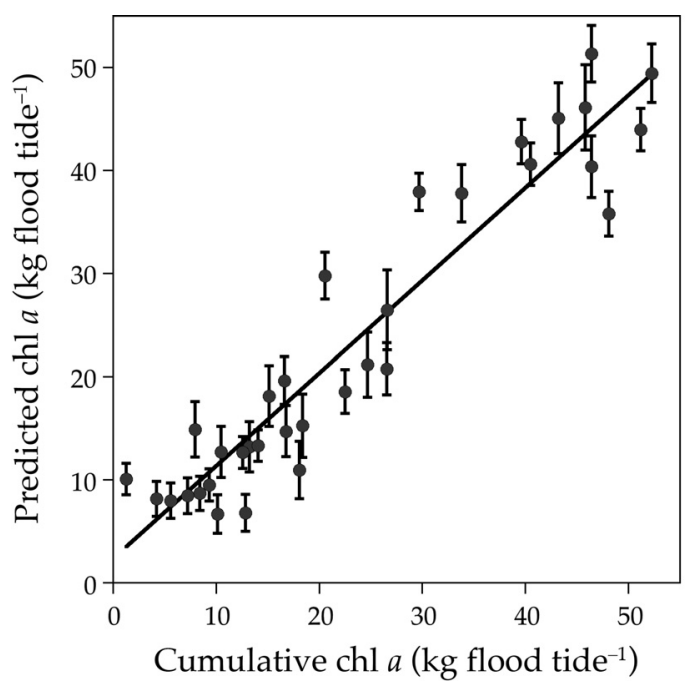

Fig. 8. Observed versus predicted values for cumulative chl $a$ on flood tides based on a generalized linear model with salinity, wind speed and northern wave height as predictor variables
The size distribution of the Austrovenus stutchburyi population in Waitati Inlet followed a clear adult mode with a range between 5.9 and $61 \mathrm{~mm}$ total length and an average size of $30.17 \mathrm{~mm}$ (Fig. 9A). Estimates of per capita clearance rates of the water exchanged between the coastal ocean and the inlet ranged from a minimum of $0.02 \mathrm{l}$ ind..$^{-1}$ tidal cycle $^{-1}$ for the smallest individuals and increased geometrically with size to $26.371 \mathrm{ind}^{-1}$ tidal $_{\text {cycle }}{ }^{-1}$ (Fig. 9B). The average per capita clearance rate was
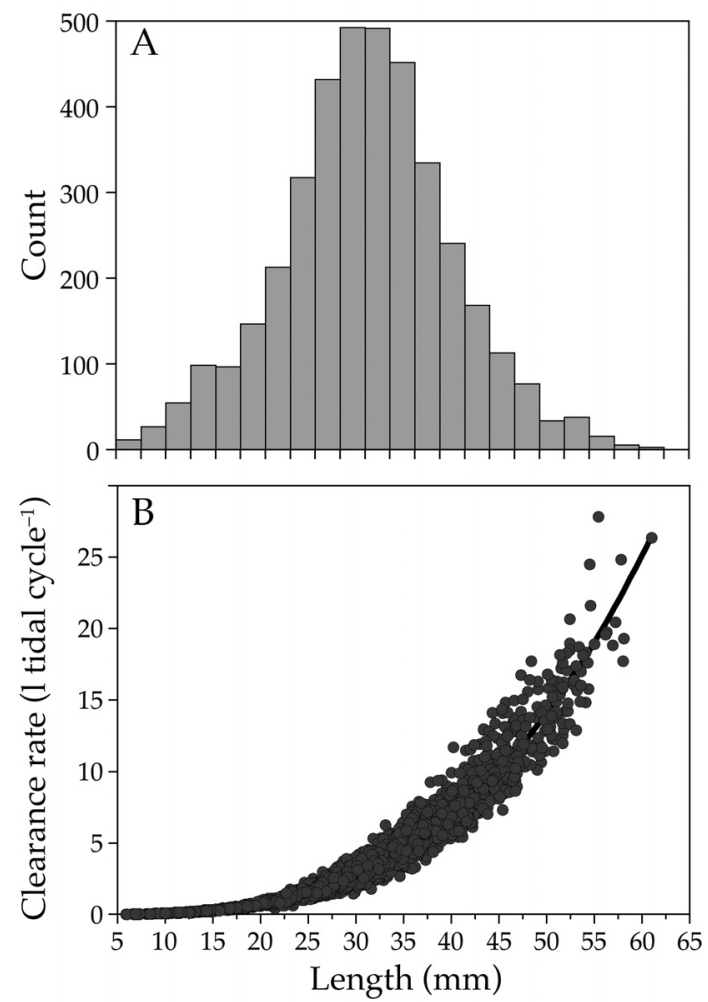

Fig. 9. (A) Size-frequency distribution of Austrovenus stutchburyi in Waitati Inlet $(\mathrm{n}=3869)$ and $(\mathrm{B})$ estimates of sizespecific clearance rates by $A$. stutchburyi

Table 1. Relative explanatory power of environmental indicators for cumulative mass of chl a on flood tides using Akaike's information criterion corrected for small sample sizes $\left(\mathrm{AIC}_{\mathrm{c}}\right)$ model selection criteria. Each of the models included sample period (ordinal, 5 levels) as an extra factor. $k$ : no. of model parameters; RSS: residual sum of squares; $\Delta_{i}$ : difference in model AIC ${ }_{c}$ from minimum $\mathrm{AIC}_{\mathrm{c} i} w_{i}$ : model $\mathrm{AIC}_{\mathrm{c}}$ weight

\begin{tabular}{|c|c|c|c|c|c|c|c|}
\hline Model & $k$ & RSS & $\mathrm{r}^{2}$ & $\mathrm{AIC}_{\mathrm{c}}$ & $\Delta_{i}$ & $w_{i}$ & $\begin{array}{l}\text { Factor } \\
\text { weight }\end{array}$ \\
\hline Wind $\left(\mathrm{m} \mathrm{s}^{-1}\right)$ & 4 & 5532.8 & 0.66 & 206.3 & 0.0 & 0.0000 & 0.99 \\
\hline Wind $\left(\mathrm{m} \mathrm{s}^{-1}\right) \times$ north wave height $(\mathrm{m})$ & 5 & 5174.1 & 0.67 & 206.3 & -0.1 & 0.0000 & 0.91 \\
\hline North wave height (m) & 4 & 4935.4 & 0.70 & 205.3 & -1.0 & 0.0000 & \\
\hline Salinity (ppt) & 4 & 1964.3 & 0.75 & 161.1 & -45.2 & 0.0000 & 1 \\
\hline Salinity $(\mathrm{ppt}) \times$ north wave height $(\mathrm{m})$ & 5 & 1399.8 & 0.82 & 141.1 & -65.2 & 0.0011 & \\
\hline Salinity $(\mathrm{ppt}) \times$ wind $\left(\mathrm{m} \mathrm{s}^{-1}\right)$ & 5 & 987.0 & 0.88 & 132.5 & -73.9 & 0.0856 & \\
\hline Salinity $(\mathrm{ppt}) \times$ wind $\left(\mathrm{m} \mathrm{s}^{-1}\right) \times$ north wave height $(\mathrm{m})$ & 6 & 802.0 & 0.90 & 127.7 & -78.6 & 0.9130 & \\
\hline
\end{tabular}


estimated to be $3.67 \mathrm{lind}^{-1}$ tidal $_{\text {cycle }}{ }^{-1}$. The estimated average volume filtered of the water exchanged per tidal cycle was $3968908 \pm 224286 \mathrm{~m}^{3}$, which represented, on average, $43 \%$ of the tidal exchange of water, with a range of $15-63 \%$ volume filtered. The average volume of water filtered per gDW of $A$. stutchburyi tissue was $14.82 \pm 0.83 \mathrm{lgDW}^{-1}$ tidal cycle $^{-1}$.

\section{DISCUSSION}

The data and results of the present study demonstrated that Waitati Inlet was a net sink for particulate carbon from coastal phytoplankton and a net exporter of $\mathrm{NH}_{4}$ to the coastal ocean. Continuous measurement of flow and of chl a concentration over a series of tidal cycles provided the basis for high resolution measurements of total fluxes of phytoplankton between Waitati Inlet and the coastal ocean. The patterns that we observed on net fluxes of organic matter were consistent with a large influence of filtration of water by the resident population of Austrovenus stutchburyi, which had a total inlet biomass of $14161.7 \pm 1081.8$ t at the time of study (Miller \& Black 2019). Wind stress, wave transport and salinity were each significant statistical predictors of chl a concentrations entering the inlet on the flood tides, indicating that exogenous oceanographic forcing conducive to retention of coastal water likely affected the delivery of phytoplankton to the inlet that was then available to be filtered by bivalves. If we assume that the clearance of phytoplankton from the water that exchanged with the outer coast was dominated by A. stutchburyi, then total estuary clearance rates accounted for between 15 and $63 \%$ of the exchanged water volume. These estimates fall within the range of published values for biomass-specific clearance rates for intertidal bivalves, but several caveats must be considered along with our estimates. Together, these data highlight the important physical and biological interactions between estuaries and open coastal systems, and particularly, the interactions between exogenous oceanic forcing and bivalve filter feeding on the flux of organic matter and nutrients between systems.

Nitrogen is generally the limiting nutrient for primary production in coastal marine systems (Vitousek \& Howarth 1991). We observed that Waitati Inlet was a net exporter of $\mathrm{NH}_{4}$ during the course of our study and a net importer of phytoplankton. The observed pattern is consistent with the idea that mixing of estuarine water with coastal water on ebb tides likely resulted in increased pelagic primary production in water that was retained near the estuary entrance during oceanographic conditions conducive to onshore retention. Ocean conditions of onshore wind stress and wave transport tend to increase retention of neritic water near the entrance of the inlet, and the observed increased phytoplankton concentrations were more likely to be transported back into the estuary on the flood tide. Hence, onshore conditions likely increased the 'exposure time' for water moving between the inlet and coastal ocean (sensu Delhez 2013). The resulting coupling mechanism provides a basis for a strong positive feedback between nutrient enrichment within the inlet and enhanced productivity of the coastal ocean, with net fluxes of phytoplankton into the inlet on flood tides. As the nutrient concentrations of estuarine water are altered by extensive filter feeding by bivalves, the positive feedback and cycling of nitrogen is highly dependent on an abundant population of bivalves within the inlet. In the absence of sufficient biogeochemical cycling of nutrients and/or increased land-based inputs, nutrient concentrations would likely increase beyond the observed average $\mathrm{NH}_{4}$ concentration of $0.44 \pm$ $0.11 \mu \mathrm{mol} \mathrm{l^{-1 }}$. Currently, national numeric nutrient guidelines are not set for estuaries and coastal waters; however, coastal managers are beginning to recommend regionally dependent trigger value thresholds for nutrients close to or below the values we observe here (ANZECC \& ARMCANZ 2000).

Observations of extensive filter feeding and cycling of $\mathrm{NH}_{4}$ by dense bivalve beds have provided the basis for a strong link between ecosystem services provided by bivalves and coastal eutrophication processes (Dame \& Dankers 1988, Dame 2016). In the absence of bivalve filter feeding, the positive feedback between nutrient outwelling in estuaries and stimulation of coastal phytoplankton blooms can result in shifts to alternate degraded states of estuarine systems (Beukema \& Cadée 1996, Kirby 2004). The patterns that we observed in the present study suggest that much of the variability in this process can be physically mediated by coastal ocean processes, highlighting the need to understand ecosystem connectivity between estuaries and the open coast to understand internal dynamics within estuarine systems.

Observations of loss or decline of bivalves in several large estuarine systems have highlighted their role in the chain of vital processes that define ecosystem function. For example, the Dutch Wadden Sea is characterized by extensive tidal channels and large tidal exchange with the open coast, coupled with high rates of nutrient input from agriculture. In 1990, 
after 3 yr of recruitment failure and high fishing mortality, extensive beds of mussels Mytilus edulis and cockles Cerastoderma edule were lost from large parts of the system. The result was early onset and proliferation of phytoplankton blooms throughout the Wadden Sea and enhancement of the detrital pathways for flux of organic matter through the benthic food web, primarily through the benthic clam Macomona balthica (Beukema \& Cadée 1996). In the Chesapeake Bay system, extensive fishery mortality and excess coastal runoff resulted in extensive losses of oyster Crassostrea virginica reef habitats from the system beginning in the late 1800s. The result has been extensive coastal eutrophication and a state change in the estuarine ecosystem (Kirby 2004). These examples highlight the link between the multiple stressors of fisheries mortality, nutrient pollution and eutrophication in estuarine systems and highlight the important feedback between bivalve filter feeding and cycling of organic matter and nutrients (Thrush et al. 2006).

In Waitati Inlet, the commercial fishery for cockles (A. stutchburyi) has increased from 16 t harvested in 1990 to 906 t landed in 2019, with additional recreational and customary harvesting pressures (Miller \& Black 2019). Declines in abundance have occurred within the commercial beds, which cover much of the deeper habitat along the seaward channels of the inlet (Irwin 2004). Nevertheless, estimates of wholeinlet biomass, which include large unfished regions of the inlet, have not resolved significant changes since the beginning of commercial fishing, reflecting an increase in biomass in unfished regions of the inlet. Those habitats not subjected to commercial fishing are in the high intertidal mudflat habitats in the inner reaches of the inlet, where filtration capacity and growth rates are reduced by immersion time, variations in flow rate, sedimentary environment (Jones et al. 2011) and food quality (Pawson 2004). The feeding rate is primarily constrained by the time of immersion (Beentjes 1984) and distance from the tidal entrance (Larcombe 1971). In the present study, net change in phytoplankton biomass relative to flux of phytoplankton on flood tides likely reflected the consumption of phytoplankton by the bivalves within the inlet as modelled by a Type II functional response curve. The observed relationship indicated that the inlet could host a larger population of bivalves with higher consumption capacity before reaching the asymptote of the functional response curve. It is likely that changes in biomass, as well as the distribution of biomass across the intertidal zone, affect the filtration capacity of the whole inlet population (Dobbinson et al. 1989). A shift in the distribution of bivalves toward more shallow habitats with less immersion time would decrease the efficiency of filter feeding within a tidal cycle and hence reduce the net change in flux of phytoplankton within a tidal cycle.

The data and results that we have presented make a strong case for the important interaction between bivalve filter feeding and oceanographic forcing on fluxes of phytoplankton between Waitati Inlet and the open coast. However, several important caveats must accompany our conclusions. First, we quantified phytoplankton abundance based on continuously measured chl a concentration and discrete reference samples, then calculated total fluxes of phytoplankton in terms of both mass of chl a $\left(\mathrm{kg} \mathrm{tide}^{-1}\right)$ and mass of carbon ( $\mathrm{kg} \mathrm{tide}^{-1}$ ) during each tidal cycle. In many inlets throughout the world, including Waitati Inlet, microphytobenthos comprise an important alternative source of POM (Leduc et al. 2006). Here, tidally induced resuspension of microphytobenthos can make up a large portion of the SPOM transported out of an inlet on ebb tides (de Jonge \& van Beusekom 1995). Additionally, extensive growth of macroalgae (e.g. Ulva spp.; Cornelisen et al. 2007), eelgrasses Zostera marina and epiphyte communities (e.g. Thomas et al. 2000) can make substantial contributions to the SPOM pool, particularly during high flow and wind wave periods. Accordingly, our estimates of net change in SPOM, as indicated by chl a concentration, likely had multiple sources, which we were unable to directly separate. Our estimates of clearance rates for the volume of water exchanged during each tidal cycle were based on the simplifying assumption that filter feeding by A. stutchburyi accounted for the observed decline in chl a during each tidal cycle. While undoubtedly A. stutchburyi, as the dominant species, accounted for a vast majority of the decline, there are other species and mechanisms that could account for the change. For example, Waitati Inlet hosts small but significant populations of the filter feeding bivalve Paphes australis. Additionally, processes such as interfacial water flow can trap phytoplankton into permeable sandy sediments, which can be enhanced by bioturbation, providing alternate sinks for POC (Huettel \& Rusch 2000, Volkenborn et al. 2007). Calculations of weight-specific clearance rates for the full inlet may have variability amongst season and year, as shellfish body condition fluctuates with food availability and the presence of reproductive tissue (Coughlan \& Ansell 1964, Walne 1972). Nevertheless, our estimates of biomass-specific clearance rates fall within reported values for estuarine bivalves (e.g. Riisgård 2001, Pascoe et al. 2009, Jones et al. 2011, Rosa et al. 2018), and 
it is clear from the patterns in delivery of phytoplankton to the estuary that oceanographic processes influence the fluxes of POM total particulate organic carbon and nitrogen available to bivalves on each tidal cycle.

Our data provide the basis to determine the net exchange of the SPOM pool during tidal cycling in Waitati Inlet. While each of the sources represent autotrophic contributions, each of the potential sinks-bivalve filter feeding, particle capture by other invertebrates, settlement and incorporation into the detrital food web-represent heterotrophic pathways. We can therefore calculate whether tidally induced fluxes of SPOM into Waitati Inlet resulted in a net heterotrophic or a net autotrophic system, in terms of the particulate pool. In the present study, we observed that on average there is a $43 \%$ decline in the SPOM pool during tidal cycles with a minimum net change of $15 \%$ and a maximum net change of $63 \%$. The result was that during our series of continuous observations over 40 tidal cycles, the Waitati Inlet system was functioning as a net heterotrophic system in terms of the SPOM pool only $25 \%$ of the time. Much of the observed variability between autotrophic and heterotrophic conditions was explained by conditions favourable to onshore oceanographic retention of water. These data have important consequences for understanding ecosystem function of the system (sensu Odum 1980), whereby the fluxes of organic matter and nutrients are strongly forced by the interaction of the physical oceanographic environment with food web processes, particularly the action of filter feeding bivalves.

We have demonstrated that net fluxes of SPOM between the open coast and an inlet with a narrow tidal channel are likely influenced by a chain of vital process, including coastal retention of neritic water with high nutrient concentrations likely stimulating ex-estuary phytoplankton production, tidally induced fluxes of SPOM into the inlet followed by extensive bivalve filter feeding and outwelling of nutrients to the coastal ocean. We found that much of the increases in fluxes of SPOM during flood tides could be explained by environmental processes that were conducive to coastal retention and mixing of neritic water. These data provide the basis for understanding the interaction of nutrients, pelagic primary productivity and bivalve filter feeding at the estuarycoastal ocean scale (e.g. Nakamura \& Kerciku 2000). Our results provide a valuable case study for incorporation of coastal oceanographic dynamics into studies of estuarine ecosystem function. The patterns that we observed indicate that there are vital feed- backs between subsystems, and that ecosystem function of estuaries strongly responds to physical forcing in the coastal ocean. These findings highlight the importance of considering the effects of a changing physical oceanographic environment on estuarine productivity and have important implications for understanding material dynamics in coastal ecosystems as well as informing effective ecosystem-based management of bivalve fisheries.

Acknowledgements. We thank Linda Groenewegen, Clara Schlieman, Rebecca McMullin, Sean Heseltine and Candida Savage for assistance. Technical support was provided from the Departments of Marine Science and Chemistry at the University of Otago. Monetary support was provided by grants from the National Science Challenge: Sustainable Seas (4.1.1 Ecosystem Connectivity) and from the University of Otago's Research Committee to S.R.W. and the University of Otago performance based research fund to S.H.S. We acknowledge open access meteorological data from University of Otago Department of Physics and wave data from Environment Canterbury.

\section{LITERATURE CITED}

ANZECC (Australian and New Zealand Environment and Conservation Council), ARMCANZ (Agriculture and Resource Management Council of Australia and New Zealand) (2000) Australia and New Zealand guidelines for fresh and marine water quality. Australian and New Zealand Environment and Conservation Council, and Agriculture and Resource Management Council of Australia and New Zealand, Canberra

Barnes $\mathrm{AD}$, Jochum M, Lefcheck JS, Eisenhauer N and others (2018) Energy flux: the link between multitrophic biodiversity and ecosystem functioning. Trends Ecol Evol 33:186-197

Beentjes M (1984) Aspects of feeding in Chione stutchburyi with emphasis on the difference between shore heights. BSc thesis, University of Otago

*Beukema JJ, Cadée GC (1996) Consequences of the sudden removal of nearly all mussels and cockles from the Dutch Wadden Sea. Mar Ecol 17:279-289

Boon JD, Byrne RJ (1981) On basin hyposmetry and the morphodynamic response of coastal inlet systems. Mar Geol 40:27-48

Childers DL, Day JW Jr, McKellar HN Jr (2000) Twenty more years of marsh and estuarine flux studies: revisiting Nixon (1980). In: Weinstein MP, Kreeger DA (eds) Concepts and controversies in tidal marsh ecology. Springer, Dordrecht, p 391-423

* Cornelisen CD, Wing SR, Clark KL, Bowman MH, Frew RD, Hurd CL (2007) Patterns in the $\delta^{13} \mathrm{C}$ and $\delta^{15} \mathrm{~N}$ signature of Ulva pertusa: interaction between physical gradients and nutrient source pools. Limnol Oceanogr 52:820-832

* Coughlan J, Ansell AD (1964) A direct method for determining the pumping rate of siphonate bivalves. ICES J Mar Sci 29:205-213

Dame RF (1993) The ecology of marine bivalves: an ecosystem approach. CRC Press, Boca Raton, FL

Dame RF (2016) Ecology of marine bivalves: an ecosystem approach, $2^{\text {nd }}$ edn. CRC Press, Boca Raton, FL 
Dame RF, Dankers N (1988) Uptake and release of materials by a Wadden Sea mussel bed. J Exp Mar Biol Ecol 118: 207-216

* Dame RE, Prins TC (1998) Bivalve carrying capacity in coastal ecosystems. Aquat Ecol 31:409-421

de Jonge VN, van Beusekom JEE (1995) Wind- and tideinduced resuspension of sediment and microphytobenthos from tidal flats in the Ems estuary. Limnol Oceanogr 40:776-778

Delhez ÉJM (2013) On the concept of exposure time. Cont Shelf Res 71:27-36

Dobbinson SJ, Barker MF, Jillett JB (1989) Experimental shore level transplantation of the New Zealand cockle Chione stutchburyi. J Shellfish Res 8:197-212

Doering PH, Oviatt CA (1986) Application of filtration rate models to field populations of bivalves: an assessment using experimental mesocosms. Mar Ecol Prog Ser 31: 265-275

Falco S, Niencheski LF, Rodilla M, Romero I, González del Río J, Sierra JP, Mösso C (2010) Nutrient flux and budget in the Ebro estuary. Estuar Coast Shelf Sci 87:92-102

* Farfan BC, Alvarez-Borrego S (1983) Variability and fluxes of nitrogen and organic carbon at the mouth of a coastal lagoon. Estuar Coast Shelf Sci 17:599-612

Fulford RS, Breitburg DL, Luckenbach M, Newell RIE (2010) Evaluating ecosystem response to oyster restoration and nutrient load reduction with a multispecies bioenergetics model. Ecol Appl 20:915-934

Greenfield BL, Kraan C, Pilditch CA, Thrush SF (2016) Mapping functional groups can provide insight into ecosystem functioning and potential resilience of intertidal sandflats. Mar Ecol Prog Ser 548:1-10

Heath RA (1976) Broad classification of New Zealand inlets with emphasis on residence times. NZ J Mar Freshw Res 10:429-444

Hench JL, Leichter JJ, Monismith SG (2008) Episodic circulation and exchange in a wave-driven coral reef and lagoon system. Limnol Oceanogr 53:2681-2694

*Huettel M, Rusch A (2000) Transport and degradation of phytoplankton in permeable sediment. Limnol Oceanogr 45:534-549

Hume T, Gerbeaux P, Hart D, Kettles H, Neale D (2016) A classification of New Zealand's coastal hydrosystems. NIWA Client Report No. HAM2016-062. National Institute of Water \& Atmospheric Research, Hamilton

Irwin CR (2004) The impacts of harvesting and the sustainability of a New Zealand littleneck clam (Austrovenus stutchburyi) fishery in Papanui and Waitati inlets, New Zealand. PhD thesis, University of Otago

Jack L, Wing SR, McLeod RJ (2009) Prey base shifts in red rock lobster Jasus edwardsii in response to habitat conversion in Fiordland marine reserves: implications for effective spatial management. Mar Ecol Prog Ser 381:213-222

Jakobsen HH, Markager S (2016) Carbon-to-chlorophyll ratio for phytoplankton in temperate coastal waters: seasonal patterns and relationship to nutrients. Limnol Oceanogr 61:1853-1868

Jones HFE, Pilditch CA, Bryan KR, Hamilton DP (2011) Effects of infaunal bivalve density and flow speed on clearance rates and near-bed hydrodynamics. J Exp Mar Biol Ecol 401:20-28

Jones HFE, Pilditch CA, Hamilton DP, Bryan KR (2017) Impacts of a bivalve mass mortality event on an estuarine food web and bivalve grazing pressure. NZ J Mar Freshw Res 51:370-392
Kainamu A (2011) The fishery trend and feeding capacity of the New Zealand littleneck clam, Austrovenus stutchburyi, in a southern New Zealand inlet. MSc thesis, University of Otago

Kirby MX (2004) Fishing down the coast: historical expansion and collapse of oyster fisheries along continental margins. Proc Natl Acad Sci USA 101:13096-13099

Kjerfve B, Proehl JA (1979) Velocity variability in a crosssection of a well-mixed estuary. J Mar Res 37:409-418

Kjerfve B, Proehl JA, Schwing FB, Seim HE, Marozas M (1982) Temporal and spatial considerations in measuring estuarine water fluxes. In: Kennedy VS (ed) Estuarine comparisons. Academic Press, New York, NY, p 37-51

Klinck JM, O'Brien JJ, Svendsen H (1981) A simple model of fjord and coastal circulation interaction. J Phys Oceanogr 11:1612-1626

Larcombe M (1971) The ecology, population dynamics and energetics of some soft shore molluscs. PhD thesis, University of Auckland

K Large WG, Pond S (1981) Open ocean momentum flux measurements in moderate to strong winds. J Phys Oceanogr 11:324-336

Leduc D, Probert PK, Frew RD, Hurd CL (2006) Macroinvertebrate diet in intertidal seagrass and sandflat communities: a study using C, N, and S stable isotopes. NZ J Mar Freshw Res 40:615-629

Longuet-Higgins MS (1953) Mass transport in water waves. Phil Trans R Soc A 245:535-581

McCarthy GJ, Ray NE, Fulweiler RW (2019) Greenhouse gas emissions from native and non-native oysters. Front Environ Sci 7:194

*McLeod RJ, Wing SR (2008) Influences of freshwater input on infaunal bivalves: population response to an altered salinity regime. Estuar Coast Shelf Sci 78:529-540

*McLeod RJ, Wing SR, Davis JP (2010) Habitat conversion and species loss alters the composition of carbon sources to benthic communities. Mar Ecol Prog Ser 411:127-136

Miller B, Black DW (2019) Assessment of clams (Austrovenus stutchburyi) in Waitati Inlet Otago, 2018-2019. Report to the Ministry of Primary Industries, Wellington

Murrell MC, Hagy JD, Lores EM, Greene RM (2007) Phytoplankton production and nutrient distributions in a subtropical estuary: importance of freshwater flow. Estuar Coast 30:390-402

Nakamura Y, Kerciku F (2000) Effects of filter-feeding bivalves on the distribution of water quality and nutrient cycling in a eutrophic coastal lagoon. J Mar Syst 26: 209-221

Newell RE (1988) Ecological changes in Chesapeake Bay: Are they the result of overharvesting the American oyster, Crassostrea virginica? In: Lynch MP, Drome EC (eds) Understanding the estuary: advances in Chesapeake Bay research. Chesapeake Research Consortium, Baltimore, MD, p 536-546

* Newell RIE, Cornwell JC, Owens MS (2002) Influence of simulated bivalve biodeposition and microphytobenthos on sediment nitrogen dynamics: a laboratory study. Limnol Oceanogr 47:1367-1379

*Newell SE, McCarthy MJ, Gardner WS, Fulweiler RW (2016) Sediment nitrogen fixation: a call for re-evaluating coastal $\mathrm{N}$ budgets. Estuar Coast 39:1626-1638

Nixon SW (1980) Between coastal marshes and coastal waters: a review of twenty years of speculation and research on the role of salt marshes in estuarine productivity and water chemistry. In: Hamilton P, MacDonald K 
(eds) Estuarine and wetland processes, Vol 11. Springer, Boston, MA, p 437-525

Norkko A, Villnäs A, Norkko J, Valanko S, Pilditch C (2013) Size matters: implications of the loss of large individuals for ecosystem function. Sci Rep 3:2646

O'Connell-Milne SA, Savage C, Rayment W (2016) The influence of commercial harvesting on parasite infection in the bivalve Austrovenus stutchburyi. Can J Fish Aquat Sci 73:982-989

Odum EP (1980) The status of three ecosystem-level hypothesis regarding salt marsh estuaries: tidal subsidy, outwelling, and detritus-based food chains. In: Kennedy VS (ed) Estuarine perspectives. Academic Press, New York, NY, p 485-495

Pascoe PL, Parry HE, Hawkins AJS (2009) Observations on the measurement and interpretation of clearance rate variations in suspension-feeding bivalve shellfish. Aquat Biol 6:181-190

Pawson M (2004) The cockle Austrovenus stutchburyi and chlorophyll depletion in a southern New Zealand inlet. MSc thesis, University of Otago

Riisgård HU (2001) On measurement of filtration rates in bivalves - the stony road to reliable data: review and interpretation. Mar Ecol Prog Ser 211:275-291

Robertson BM, Stevens L, Robertson B, Zeldis J and others (2016) NZ Estuary trophic index: screening tool 1. Determining eutrophication susceptibility using physical and nutrient load data. Environlink tools project: estuarine trophic index. National Institute of Water and Atmospheric Research, Auckland

Rodhouse PG, Roden CM (1987) Carbon budget for a coastal inlet in relation to intensive cultivation of suspensionfeeding bivalve mollusks. Mar Ecol Prog Ser 36:225-236

Rodriguez CA, Dettman DA, Flessa KW (2001) Effects of upstream diversion of Colorado River water on the estuarine bivalve mollusk Mulinia coloradoensis. Conserv Biol 15:249-258

Rosa M, Ward JE, Shumway SE (2018) Selective capture and ingestion of particles by suspension-feeding bivalve molluscs: a review. J Shellfish Res 37:727-746

Rutger SM, Wing SR (2006) Effects of freshwater input on shallow water infaunal communities in Doubtful Sound, New Zealand. Mar Ecol Prog Ser 314:35-47

Rynne P, Reniers A, van de Kreeke J, MacMahan J (2016) The effect of tidal exchange on residence time in a coastal embayment. Estuar Coast Shelf Sci 172:108-120

Editorial responsibility: Robinson Fulweiler,

Boston, Massachusetts, USA

Reviewed by: 3 anonymous referees
Smith AM, Wood ACL, Liddy MFA, Shears AE, Fraser CI (2010) Human impacts in an urban port: the carbonate budget, Otago Harbour, New Zealand. Estuar Coast Shelf Sci 90:73-79

Snelgrove PVR, Soetaert K, Solan M, Thrush S and others (2018) Global carbon cycling on a heterogeneous seafloor. Trends Ecol Evol 33:96-105

Srisunont C, Babel S (2016) Estimating the carrying capacity of green mussel cultivation by using net nutrient removal model. Mar Pollut Bull 112:235-243

Suanda SH, Kumar N, Miller AJ, Di Lorenzo E and others (2016) Wind relaxation and a coastal buoyant plume north of Pt. Conception, CA: observations, simulations, and scalings. J Geophys Res Oceans 121:7455-7475

Tallis HM, Wing SR, Frew RD (2004) Historical evidence for habitat conversion and local population decline in a New Zealand fjord. Ecol Appl 14:546-554

Thomas FIM, Cornelisen CD, Jande JM (2000) Effects of water velocity and canopy morphology on ammonium uptake by seagrass communities. Ecology 81: 2704-2713

Thrush SF, Hewitt JE, Gibbs M, Lundquist C, Norkko A (2006) Functional role of large organisms in intertidal communities: community effects and ecosystem function. Ecosystems 9:1029-1040

Viero DP, Defina A (2016) Water age, exposure time, and local flushing time in semi-enclosed, tidal basins with negligible freshwater inflow. J Mar Syst 156:16-29

Vitousek PM, Howarth RW (1991) Nitrogen limitation on land and in the sea: How can it occur? Biogeochemistry 13:87-115

Volkenborn N, Polerecky L, Hedtkamp SIC, Van Beusekom JEE, De Beer D (2007) Bioturbation and bioirrigation extend the open exchange regions in permeable sediments. Limnol Oceanogr 52:1898-1909

WWalne PR (1972) The influence of current speed, body size and water temperature on the filtration rate of five species of bivalves. J Mar Biol Assoc UK 52:345-374

*Winder M, Carstensen J, Galloway AWE, Jakobsen $\mathrm{HH}_{\text {, }}$ Cloern JE (2017) The land-sea interface: a source of high-quality phytoplankton to support secondary production. Limnol Oceanogr 62:S258-S271

*Wing SR, Botsford LW, Ralston SV, Largier JL (1998) Meroplanktonic distribution and circulation in a coastal retention zone of the northern California upwelling system. Limnol Oceanogr 43:1710-1721

Submitted: May 19, 2020

Accepted: October 1, 2020

Proofs received from author(s): November 20, 2020 